\title{
Winter Predation by River Otter, Lontra canadensis, on Tautog, Tautoga onitis, at Western Arm Jeddore Harbour, Halifax County, Nova Scotia, Canada, with a Review of Evidence for Resident Relict Populations of the Tautog in Nova Scotia and New Brunswick
}

\author{
JOHN GILHEN ${ }^{1}$ and KIM AABOE ${ }^{2}$ \\ ${ }^{1}$ Nova Scotia Museum of Natural History, 1747 Summer Street, Halifax, Nova Scotia B3H 3A6 Canada \\ ${ }^{2}$ RR \# 1. Head of Jeddore, Nova Scotia B0J 1P0 Canada
}

Gilhen, J., and K. Aaboe. 2008. Winter predation by River Otter, Lontra canadensis, on Tautog, Tautoga onitis, at Western Arm Jeddore Harbour, Halifax County, Nova Scotia, Canada, with a review of evidence for resident relict populations of the Tautog in Nova Scotia and New Brunswick. Canadian Field-Naturalist 122(2): 247-252.

We report winter predation by River Otter, Lontra canadensis, on Tautog, Tautoga onitis, a southern marine fish, at Western Arm Jeddore Harbour, Halifax County, Nova Scotia $\left(44^{\circ} 46^{\prime} \mathrm{N}, 63^{\circ} 03^{\prime} \mathrm{W}\right)$, on 17 February 2008 . We also discuss the distribution of Tautog in the western Atlantic Ocean, review Canadian records, and provide evidence that resident relict populations of this fish exist in Nova Scotia and New Brunswick.

Key Words: Winter predation, River Otter, Lontra canadensis, Tautog, Tautoga onitis, Western Arm Jeddore Harbour, distribution, western Atlantic Ocean, marine summer visitor, relict populations, Nova Scotia, New Brunswick, Canada.

The Tautog, Tautoga onitis (Figure 1), and Cunner, Tautogolabrus adspersus, are the only two wrasses (Labridae) known to occur in the marine coastal waters of Nova Scotia and New Brunswick, Canada. Both species have a laterally compressed body and rounded caudal fin. They have two series of blunt conical teeth in each jaw, the front row the largest (Figure 2), with rounded, crushing teeth at the rear of the mouth. Both species are found along rocky shoals, ledges, wharf pilings and wrecks and specialize in eating mussels and other molluscs and crustaceans.
The Tautog is readily distinguished from the Cunner in having the base of the pelvic fins located below the base of the pectoral fins (Cunner, behind the pectoral fins), the head is distinctly rounded in lateral view (Cunner, front of head pointed in lateral view) and the lower half of the operculum is without scales (Cunner, lower half of operculum with scales). The Tautog grows larger than the Cunner and is a stouter-bodied fish (Leim and Scott 1966). The dorsal fin has 16-17 spines and 10-11 soft rays (Cunner 18 spines and 9-10 soft rays), and an anal fin with 3 spines and 7-8 soft
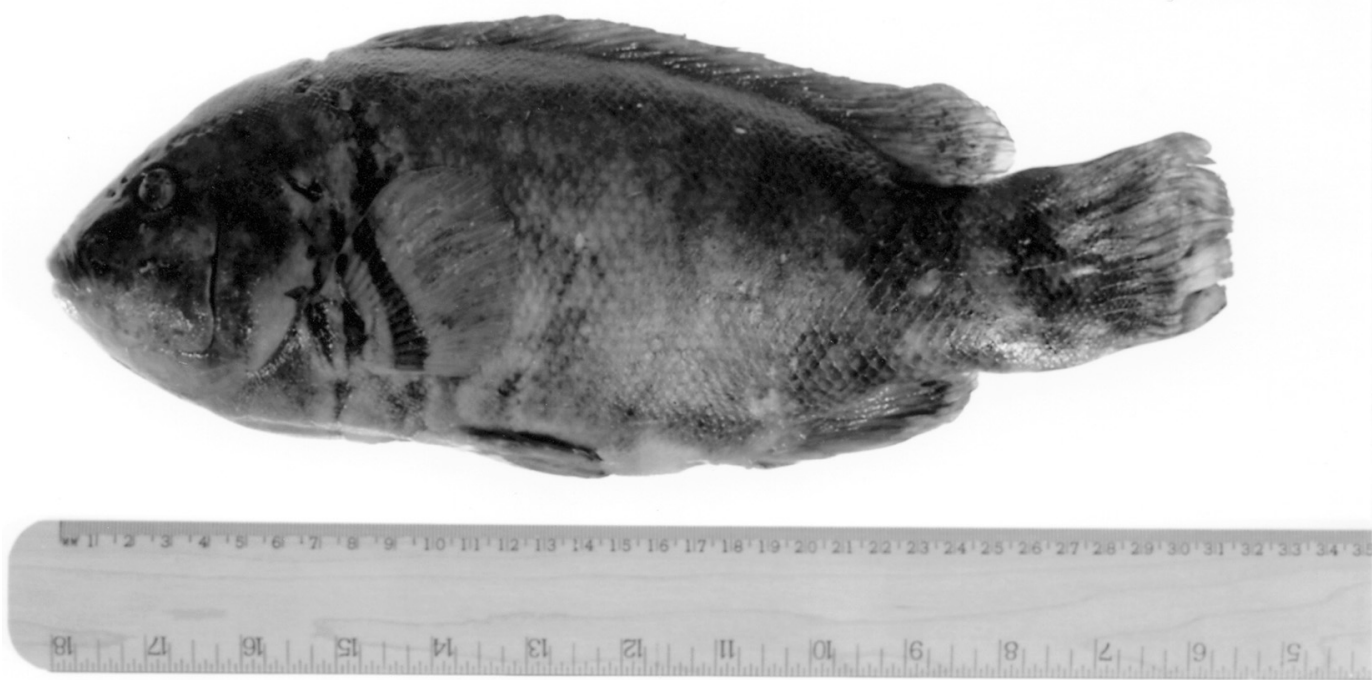

FIGURE 1. Adult Tautog, Tautoga onitis, captured in a mackerel trap set off Red Bank, St. Margaret's Bay, Halifax County, Nova

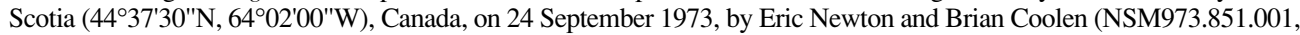
Negative Number N.2790) 
TABLE 1. Records of Tautog, Tautoga onitis, from the coastal waters of Nova Scotia and New Brunswick, Canada. NSM = Nova Scotia Museum; ARC = Atlantic Reference Centre.

\begin{tabular}{|c|c|c|c|}
\hline $\begin{array}{l}\text { Specimen } \\
\text { Number }\end{array}$ & Locality & Date & $\begin{array}{l}\text { References } \\
\text { (Collector) }\end{array}$ \\
\hline NSM950 & $\begin{array}{l}\text { Scotts Bay, } \\
\text { Kings County, Bay of Fundy, } \\
\text { Nova Scotia }\end{array}$ & 12 June 1902 & $\begin{array}{l}\text { Vladykov and MacKenzie 1935; } \\
\text { Bigelow and Schroeder 1953; } \\
\text { Leim and Scott 1966; Gilhen } 1999\end{array}$ \\
\hline NSM 1845 & $\begin{array}{l}\text { Petpeswick Inlet, } \\
\text { Halifax County, } \\
\text { Nova Scotia }\end{array}$ & 21 May 1903 & $\begin{array}{l}\text { Vladykov and MacKenzie 1935; } \\
\text { Bigelow and Schroeder 1953; } \\
\text { Leim and Scott 1966; Gilhen } 1999\end{array}$ \\
\hline 1 specimen & $\begin{array}{l}\text { Passamaquoddy Bay, } \\
\text { Bay of Fundy, } \\
\text { New Brunswick }\end{array}$ & 1910 & $\begin{array}{l}\text { Huntsman 1922; } \\
\text { Leim and Scott } 1966\end{array}$ \\
\hline 1 specimen & $\begin{array}{l}\text { Cranberry Head, } \\
\text { Cumberland County, } \\
\text { Nova Scotia }\end{array}$ & 1912 & $\begin{array}{l}\text { Fowler 1915; } \\
\text { Vladykov and } \\
\text { MacKenzie 1935; Bleakney 1963; } \\
\text { Leim and Scott } 1966\end{array}$ \\
\hline 1 specimen & $\begin{array}{l}\text { St. Croix River at Oak Bay, } \\
\text { Bay of Fundy, } \\
\text { New Brunswick }\end{array}$ & 1934 & $\begin{array}{l}\text { M'Gonigle and Smith 1936; } \\
\text { Leim and Scott } 1966\end{array}$ \\
\hline 1 specimen & $\begin{array}{l}\text { St. Croix River at Oak Bay, } \\
\text { Bay of Fundy, } \\
\text { New Brunswick }\end{array}$ & 1935 & $\begin{array}{l}\text { M'Gonigle and Smith, 1936; } \\
\text { Leim and Scott } 1966\end{array}$ \\
\hline 3 observed & $\begin{array}{l}\text { Mahone Bay, } \\
\text { Lunenburg County, } \\
\text { Nova Scotia }\end{array}$ & $\begin{array}{l}2 \text { June } 1962 \\
2 \text { July } 1962 \\
9 \text { September } 1962\end{array}$ & Bleakney 1963 \\
\hline NSM971.095.001 & $\begin{array}{l}\text { Off Peggys Cove, } \\
\text { Halifax County, } \\
\text { Nova Scotia }\end{array}$ & 1 October 1971 & McKay and Gilhen $1974^{*}$ \\
\hline ARC8600898 & $\begin{array}{l}\text { Dilligent River, } \\
\text { Cumberland County, } \\
\text { Nova Scotia }\end{array}$ & July 1973 & $\begin{array}{l}\text { C. Erbland } \\
\text { (collector) }\end{array}$ \\
\hline NSM973.851.001 & $\begin{array}{l}\text { Red Bank, } \\
\text { St Margarets Bay, } \\
\text { Halifax County, } \\
\text { Nova Scotia }\end{array}$ & 24 September 1973 & $\begin{array}{l}\text { Eric Newton and } \\
\text { Brian Coolen } \\
\text { (collectors) }\end{array}$ \\
\hline NSM87506 & $\begin{array}{l}\text { Red Bank, } \\
\text { St. Margarets Bay, } \\
\text { Halifax County, } \\
\text { Nova Scotia }\end{array}$ & 11 July 1974 & $\begin{array}{l}\text { Eric Newton and } \\
\text { Brian Coolen } \\
\text { (collector) }\end{array}$ \\
\hline ARC8601073 & $\begin{array}{l}\text { Passamaquoddy Bay, } \\
\text { New Brunswick }\end{array}$ & July 1980 & Scott and Scott 1988 \\
\hline ARC9512362 & $\begin{array}{l}\text { Eel Brook Lake, } \\
\text { Yarmouth County, } \\
\text { Nova Scotia }\end{array}$ & 4 June 1981 & $\begin{array}{l}\text { Albert d'Entremont } \\
\text { (collector) }\end{array}$ \\
\hline NSM12676 & $\begin{array}{l}\text { Eel Brook Lake, } \\
\text { Yarmouth County, } \\
\text { Nova Scotia }\end{array}$ & 17 May 1999 & $\begin{array}{l}\text { Albert d'Entremont } \\
\text { (collector) }\end{array}$ \\
\hline NSM88251 & $\begin{array}{l}\text { Western Arm Jeddore Harbour, } \\
\text { Halifax County, } \\
\text { Nova Scotia }\end{array}$ & 17 February 2008 & $\begin{array}{l}\text { Kim Aaboe } \\
\text { (collector) }\end{array}$ \\
\hline
\end{tabular}

rays (Cunner 3 spines and 9 soft rays), about 70 lateral line scales (Cunner about 40) [Coad et al. 1995].

On the morning of 17 February 2008 Kim Aaboe observed a River Otter, Lontra canadensis, at Western Arm Jeddore Harbour, Halifax County, Nova Scotia $\left(44^{\circ} 46^{\prime} \mathrm{N}, 63^{\circ} 03^{\prime} \mathrm{W}\right)$, with a Tautog it had captured as prey. KA was able to photograph the River Otter consume all but the head of this fish (Figure 3). He recovered the head and it has been added to the Nova Sco- tia Museum of Natural History fish collection (NSM 88251). The Western Arm Jeddore Harbour site represents the ninth locality from which the Tautog has been taken in the coastal waters of New Brunswick and Nova Scotia (Table 1). Winter capture of a Tautog at Western Arm Jeddore Harbour suggests a resident population exists on the Eastern Shore of Nova Scotia, and supports Bleakney's (1963) theory that a relict population exists at nearby Petpeswick Inlet (Figure 4). 


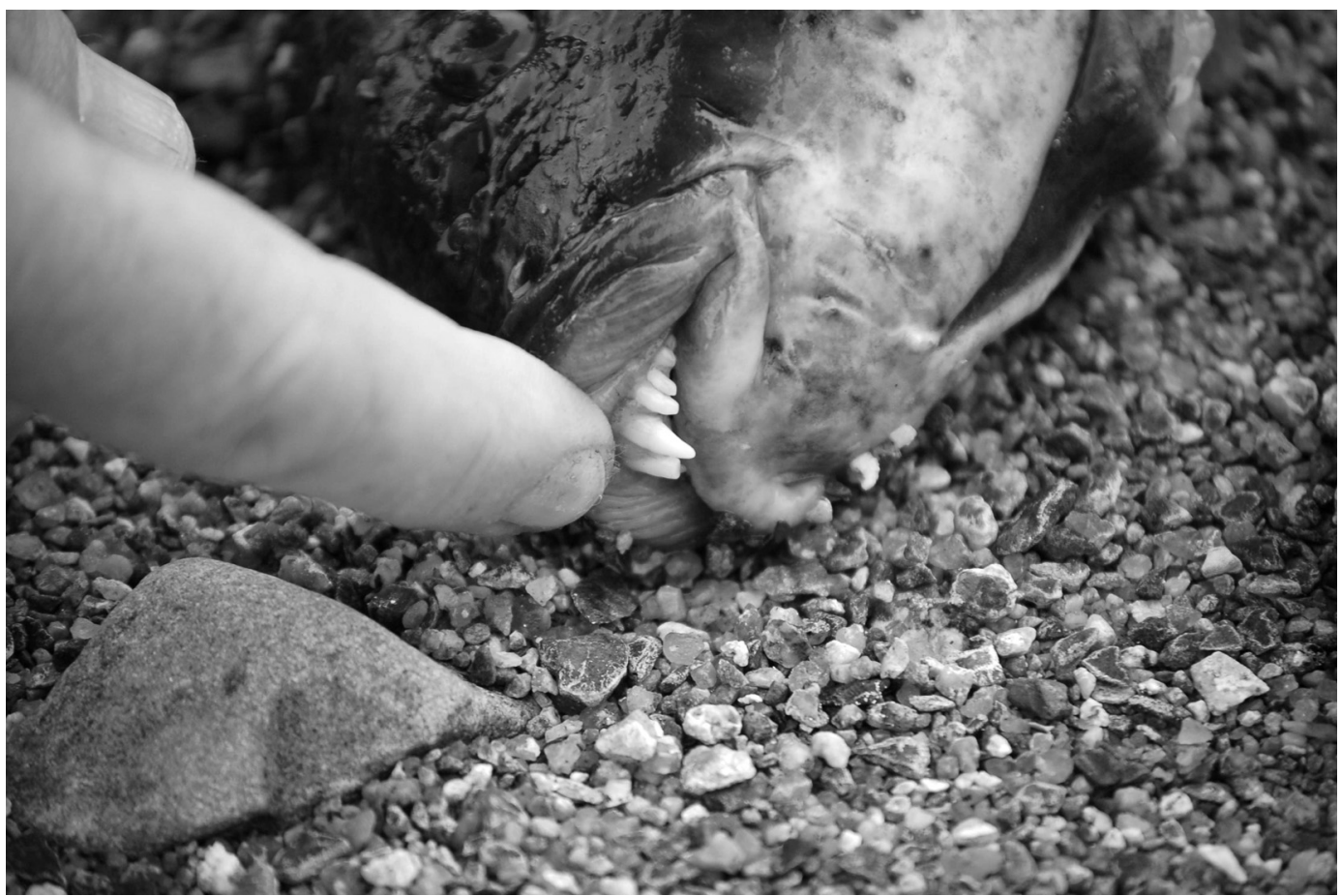

FIGURE 2. Head of Tautog, Tautoga onitis, from Western Arm Jeddore Harbour, Halifax County, Nova Scotia, 17 February 2008, showing blunt conical teeth (NSM.88251).

\section{Distribution}

The Cunner is a common native marine fish widespread in Atlantic Canada. Determining abundance and exact distributional status of the Tautog is complicated. Early accounts (Mitchill 1815: 359-402; Perley 1852) agree that the center of abundance for Tautog lies to the south of Cape Cod, and suggest that the species was introduced north of Cape Cod. Perley (1850) added: "northern waters seem to agree with this fish, for it has extended its range along the coasts of Massachusetts and Maine, and is now taken in St. John Harbour, New Brunswick. During the season of 1851, many Tautog were for sale in the fish market at St. John". Bigelow and Schroeder (1953) state that most authors who have written about this species have accepted Mitchill's (1815) statement that the Tautog is not native north of Cape Cod, and was introduced there shortly before 1814. However, they add: "But it seems far more likely that the anonymous writer who stated in the Glouchester Telegraph of May 5, 1860, that Tautog had been plentiful there many years before, and had merely reappeared after a period of scarcity, was correct; also that this reappearance would have taken place in any event, even if none had been liberated north of Cape Cod." We agree with the anonymous writer, and with Leim and Scott (1966), who give the distribution of Tautog as Atlantic coast of North America from slightly east of Halifax, Nova Scotia, to South Carolina but most abundant between Cape Cod and Delaware Bay.

We also agree with Bleakney (1963) who postulated that because our coastal waters were considerably warmer a few thousand years ago, there exists the possibility of relict disjunct populations of this species in the more protected bays of Nova Scotia. At such sites summer temperatures must be warm enough to support the incubation of the floating eggs. We suggest that some individuals of southern Tautog, along with many other subtropical and tropical fishes, migrate north during the warm summer months and visit the coastal waters of Nova Scotia (Gilhen 1986) and New Brunswick. It is not known if these southern migrants contribute to the local gene pools of small northern relict populations.

The first recorded occurrence of the Tautog in the coastal waters of Nova Scotia was documented in Accession Book Number 1 by Harry Piers, Curator of the Provincial Museum of Nova Scotia (Gilhen 1999). Under Accession Number 950, Piers records a specimen 19.5 inches $(49.5 \mathrm{~cm})$ in length, from Scotts Bay, Kings County, Bay of Fundy, Nova Scotia, captured by T. Vardy Hill on 12 June 1902. Piers states, "New to Nova Scotia!" (Table 1).

Piers recorded a second specimen under Accession Number 1845 . He purchased one of two specimens for 


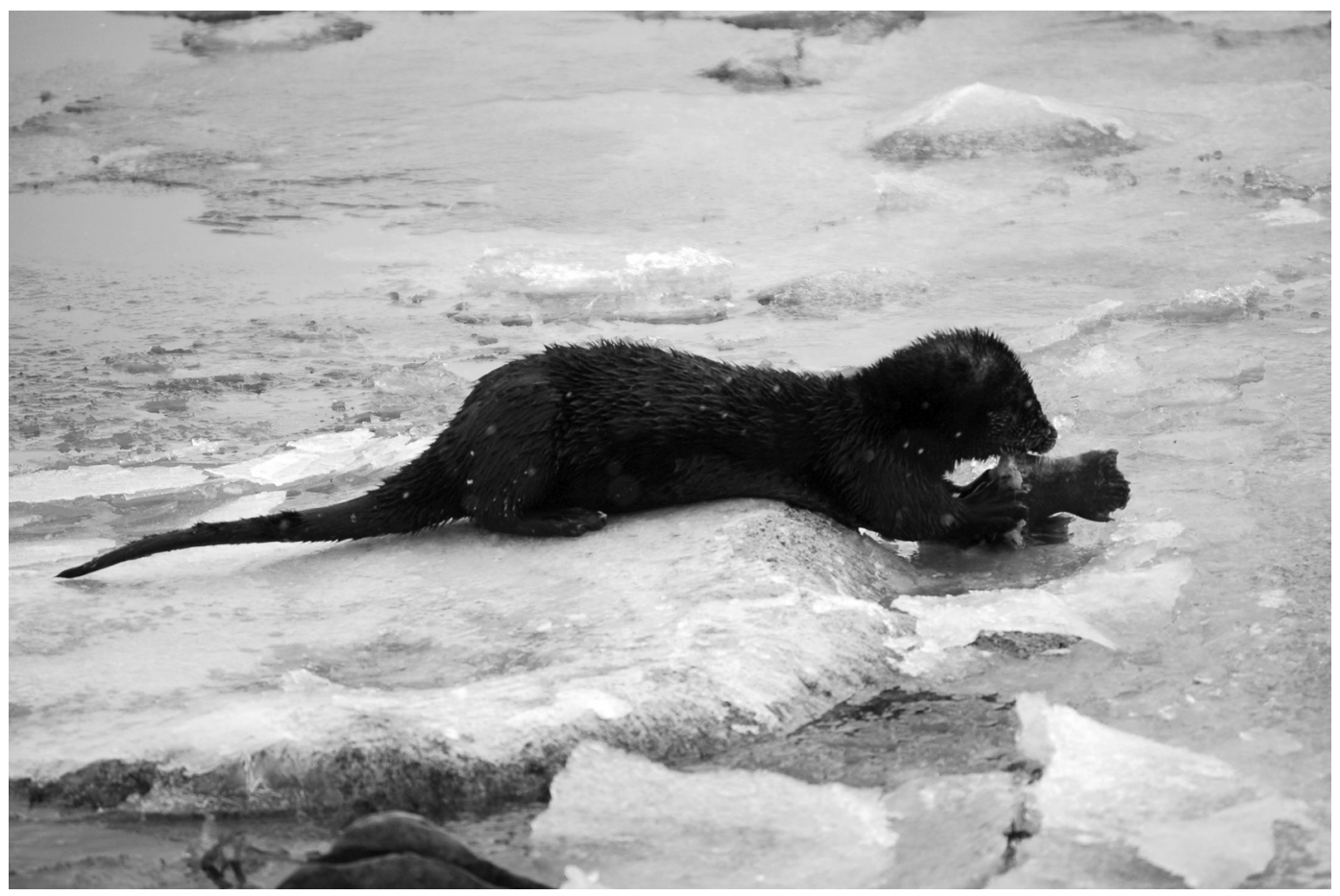

FIgURE 3. River Otter, Lontra candensis, eating a Tautog, Tautoga onitis, at Western Arm Jeddore Harbour, Halifax County, Nova Scotia, on 17 February 2008.

$\$ 0.35$ in the market, both taken on 21 May 1903 in Petpeswick Inlet, Halifax County, Nova Scotia. The length to base of caudal fin of the one purchased was $13 \frac{1}{8}$ inches $(33.2 \mathrm{~cm})$, and the second one was about 19 inches $(48.2 \mathrm{~cm})$ long. Piers stated "The woman who had them called them Black Bass".

During the summers of 1911 and 1912, D. G. Metheny collected fish at Cranberry Head, Nova Scotia, and included a Tautog in his list of 18 species (Fowler 1915). This specimen represents the third record for Nova Scotia. Vladykov and MacKenzie (1935) included the Cranberry Head record and added Yarmouth County to the locality. Bleakney (1963), however, pointed out that the only Cranberry Head in Nova Scotia is on the Bay of Fundy shore of Cumberland County.

Leim and Scott (1966) state that prior to 1957 Tautog were rarely reported from Canadian waters. They reported on three records from Passamaquoddy Bay, Bay of Fundy, New Brunswick: one about 1910 (Huntsman 1922) and two in 1934 and 1935 (M'Gonigle, and Smith 1936). Leim and Day (1959), Leim and Scott (1966), and Bleakney (1963) report that large numbers of Tautog were caught in Eel Brook Lake, a marine inlet with shallows covered in beds of blue mussel, Mytilus sp., in Yarmouth County, Nova Scotia. A sport fishery suddenly developed at Eel Brook Lake and about 2000 fish were caught in 1957 and about 450 were caught in 1958 .
Bleakney (1963) established a fifth locality record for Tautog in Nova Scotia. On 2 July 1962 he speared an $18 \% / 4$ inch $(47.4 \mathrm{~cm})$ six pound $(13.2 \mathrm{~kg}$ ) female Tautog off Crane Point, Marvin Island at Chester Basin in Mahone Bay. Broken shells of the horse mussel, Volsella modiolus, and common periwinkle, Littorina littorea, were in its stomach. The body cavity was extended by the greatly enlarged ovaries which contained eggs of different sizes, including a great many fully mature ones $1.0 \mathrm{~mm}$ in diameter. On 9 September 1962 while snorkeling over the same shoal Mr. H. Foote observed two more Tautogs, a large dark one and a smaller pale one. Bleakney reasoned this indicates the possibility of local spawning activity by a relict population of Tautoga onitis in the warmer inner reaches of Mahone Bay.

MacKay and Gilhen (1974*) communicated regularly with fishermen Eric Newton and Brian Coolen, who had a series of mackerel traps set in St. Margaret's Bay. They captured three Tautog, one off Peggys Cove, 1 October 1971, and two off Red Bank; the first on 24 September 1973 and second on 11 July 1974. We do not know if the Mahone Bay and St. Margaret's Bay records represent a single relict population or two separate relict populations.

The spring capture (21 May 1903) at Petpeswick Inlet and now a winter record (17 February 2008) at nearby Western Arm Jeddore Harbour strongly suggest a resident relict population of Tautog exists on the east- 


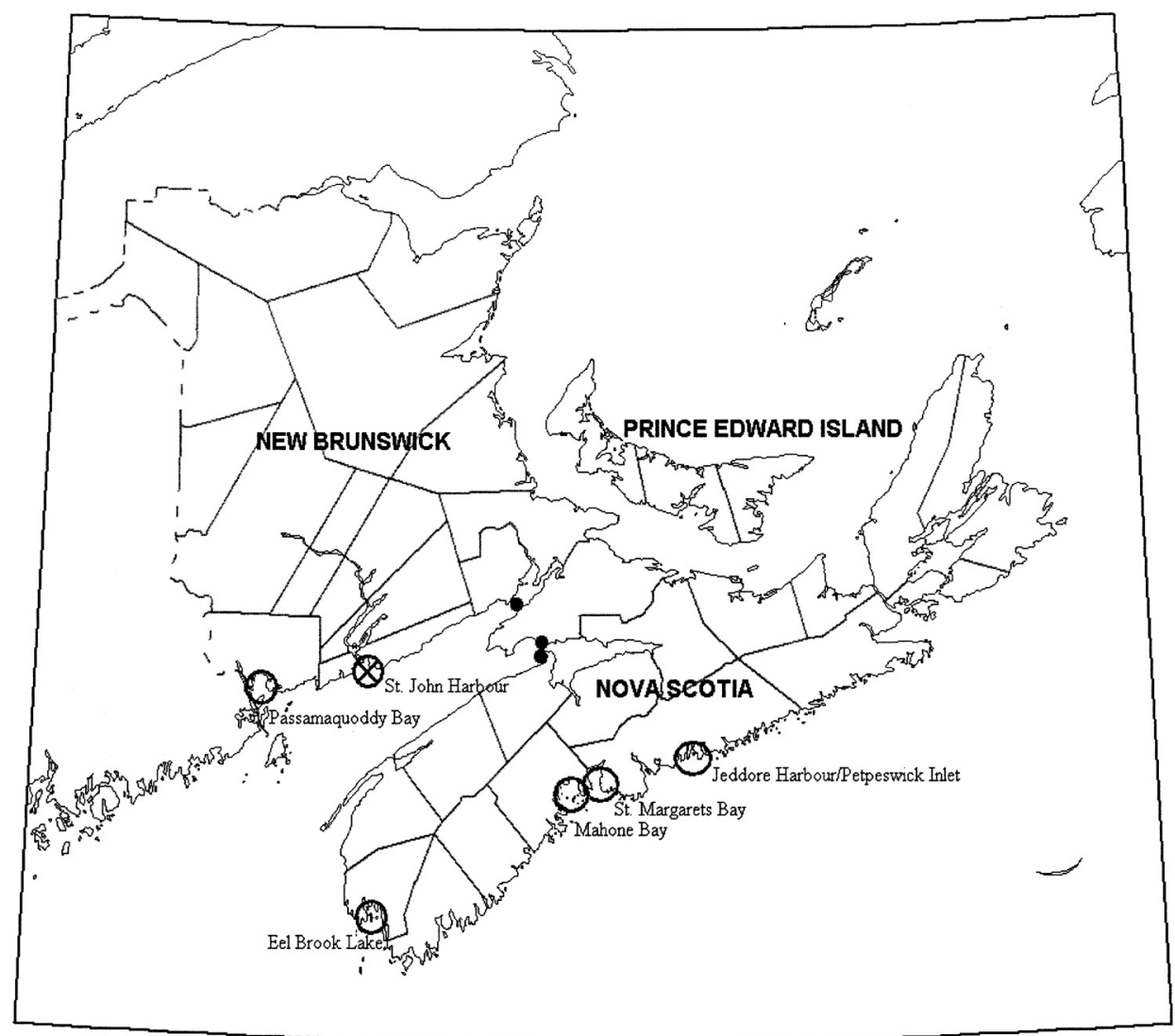

FIGURE 4. Map of maritime provinces of Canada. Closed circles represent localities where Tautog, Tautoga onitis, were captured. Open circles represent multiple captures, in areas where relict populations are believed to exist. Open circle with inside $\mathrm{X}$ represents a possible commercially extinct population.

ern shore of Nova Scotia. Also, the discovery of mature eggs in an adult female at Mahone Bay by Bleakney (1963) and the occurrence of small juveniles at Eel Brook Lake (Scott and Scott 1988; personal communication with Albert d'Entremont, West Pubnico) provide further evidence that spawning probably occurs in both localities on the south shore of Nova Scotia.

The number of individuals of Tautog in these northern relict populations must be small and this would account for the commercial extinction of the population in Saint John harbour, New Brunswick, in 1851 and the near extirpation of the population at Eel Brook Lake, Nova Scotia, following a sport fishery in 1957 and 1958.

\section{Acknowledgments}

We thank Andrew Hebda, Curator of Zoology, Nova Scotia Museum, and two anonymous reviewers for their comments on the manuscript. Dr. Derek Davis donated the Tautog specimen to the Nova Scotia Museum of Natural History. Lou Van Guelpen, Curator of Fishes and Collections Manager, provided records of Tautog from the Atlantic Reference Centre, St. Andrews, New Brunswick. Ron E. Merrick, Media Services, Nova Scotia Department of Education, took the photograph in Figure 1. Albert d'Entremont, West Pubnico, Nova Scotia, has been a source of information on unusual marine fishes in Nova Scotia waters and we value his opinion on the status of Tautog at Eel Brook Lake. We also thank Christina McCorry, Acting Registrar, Nova Scotia Museum of Natural History, for developing the distribution map and Katherine Ogden for completing the map (Figure 4).

\section{Documents Cited (marked * in text)}

McKay, K., and J. Gilhen. 1974. The occurrence of unusual fishes in the vicinity of Prospect and St. Margaret's Bay, Nova Scotia. Bedford Institute Contribution. Unpublished manuscript: 32 pages + Appendix I, 13 pages.

\section{Literature Cited}

Bigelow, H. B., and W. C. Schroeder. 1953. Fishes of the Gulf of Maine. United States Fish and Wildlife Service, Fisheries Bulletin 74. 53: 577. 
Bleakney, J. S. 1963. Notes on the distribution and reproduction of the fish Tautoga onitis in Nova Scotia. Canadian Field-Naturalist 77 (1): 64-65.

Coad, B. W., with H. Waszczuk, and I. Labignan. 1995. Encyclopedia of Canadian Fishes. Canadian Museum of Nature, Ottawa, and Canadian Sportsfishing Productions, Waterdown, Ontario. viii + 928 pages, 128 colour plates.

Fowler, H. W. 1915. Fishes from Eastern Canada. Nova Scotia. Proceedings of The Academy of Natural Sciences of Philadelphia 67: 517.

Gilhen, J. 1986. Sub-Tropical and Tropical Fish in Nova Scotia. The Occasional (An occasional journal for Nova Scotian Museums). Nova Scotia Museum. Volume 10(2): 16-21.

Gilhen, J. 1999. Fishes of Nova Scotia: Species recorded in the accession books of Harry Piers from 1899 to 1939. Curatorial Report Number 89. 153 pages, 1-107 Plates. Nova Scotia Museum, Halifax, Nova Scotia.

Huntsman, A. G. 1922. The fishes of the Bay of Fundy. Contribution to Canadian Biology, 1921. 3: 49-72.

Leim, A. H., and L. R. Day. 1959. Records of uncommon and unusual fishes from eastern Canadian waters, 1950-1958. Journal of the Fisheries Research Board of Canada, 16 (4): 503- 514 .
Leim, A. H., and W. B. Scott. 1966. Fishes of the Atlantic coast of Canada. Bulletin 155. Fisheries Research Board of Canada. Ottawa.

M'Gonigle, R. H., and M. W. Smith. 1936. Three rare fishes from Passamaquoddy Bay, N. B. Proceedings of the Nova Scotian Institute of Science 19 (2): 160.

Mitchill, S. L. 1815. The fishes of New York. Transaction of the Literary and Philosophical Society New York 1: 355492.

Perley, M. H. 1850. Statements in relation to the fisheries of the Bay of Fundy. Proceedings of the Boston Society of Natural History 3: 374.

Perley, M. H. 1852. Reports on the sea and river fisheries of New Brunswick. Fredericton, New Brunswick. 294 pages. Descriptive catalogue [in part] of the fishes of New Brunswick and Nova Scotia. Second edition, 50 pages. Fredericton. [Pages 118-159 of Report upon the fisheries of the Bay of Fundy].

Scott, W. B., and M. G. Scott. 1988. Atlantic Fishes of Canada. Canadian Bulletin of Fisheries and Aquatic Sciences 219: $x x x+731$ pages.

Vladykov, V. D., and R. A. McKenzie. 1935. The marine fishes of Nova Scotia. Proceedings of the Nova Scotian Institute Science 1934-1935, 19: 17-113.

Received 11 August 2008

Accepted 29 May 2009 